\title{
Effect of Partial Substitution of Rice Bran for the Yellow Corn (Maize) on Broiler Performance
}

\author{
Aqeel Y. AlShukri ${ }^{1}$, Ammar H. AREAAER ${ }^{2}$, Tariq S. Almrsomi ${ }^{3}$, Khlil A. Alfartosi ${ }^{4}$ \\ College of Agriculture, University of Kufa, Najaf, Iraq
}

\begin{abstract}
This study was carried out at the poultry farm of Animal Resources Dept. / College of Agricultural/ University of Kufa during the period from 16/9/2014 to 21/10/2014 to investigate the effect of partial replacement of Rice bran for Yellow Corn in broiler diets on productive performance. One hundred and ninety eight chicks of commercial strain at 1 day old were used in this study the chick were individually weighed and randomly distributed into three treatments. Each treatment included three replicates (20 chicks/replicate).The treatments were as follows: Group1 control (T0) (content 50\% yellow corn + free of rice bran), Second (T1) substituted of 25\% of raw rice bran by yellow corn, third (T2) substituted of $50 \%$ of raw rice bran by yellow corn. The results revealed that TO was significantly $(P<0.05)$ higher than other groups in live body weight, weight gain and feed consumption at 5 week of age, whereas $T 2$ was significantly $(P<0.05)$ lower as compared with other treatments. There were significant differences between groups in feed conversion ratio. The results revealed that the treatments included 25 or $50 \%$ Rice bran showed significant differences as compared to control group (free of rice bran) in the percentage.
\end{abstract}

Keywords: Rice bran, broiler. Maize. Yellow Corn, Chicks

\section{Introduction}

The increase in the world population has led to the need to increase broiler production, but this is controlled by high cost of production especially in Iraq. Several studies were done the use of many byproducts such as rice bran. Rice bran, a byproduct of the rice industry and we will find more amount of this byproduct with the increase of rice production to feed the population. Rice bran consists of an 8-10\% of total paddy weight. Rice bran contains high levels of protein about $13 \%$, lipids $13 \%$ and Metabolizable energy about 2980 $\mathrm{Kcal} / \mathrm{kg}$ (N.R.C., 1994) with light in color, sweet in taste , moderately oily and has a slightly toasted nutty flavor(Cicero and Derosa, 2005). It has many active compound to improve the Health of birds (Santo, 2012). The objective of this study was to examine the effect of using high levels of unprocessed rice bran instead of corn on productive performance of commercial broiler.

\section{Materials \& Methods}

The present investigation was conducted at the poultry farm of Animal Resource Dept., College of Agricultural/ University of Kufa during the period from 16/9/2014 to $21 / 10 / 2014$, for a period of 5 weeks. A total of One hundred and ninety eight chicks of commercial strain at 1day old mixed sexes Ross 308 broiler chicks provided from private Hatchery in Babylon. The chicks were randomly distributed to three treatment groups of 60 chicks with three replicates per treatment (20 chicks/rep.). The initial weight per bird was between 40 - $42 \mathrm{~g}$. Chick allocated to floor pens and used straw as litter, $2 \times 2$ meters with a semi-closed system consisting of 21 room (Pen) dimensions of $200 \times 150 \mathrm{~cm}$ per pen. Duration of the experiment 35 days the chick Provided all suitable requirements for proper environment from ground the hall prepared with water and feed freely for the duration of the experiment with lighting, ventilation, heating, water and feeders. Also birds received health care and vaccines since the first day to the end of the experiment, Chicks were feed the on tow diet, starter diet during the first 21 days of age (Table 1) and the growth of the age of 22 days and up to the age of marketing (35 days). The treatments were as follows: Group1 control (T0) (content $50 \%$ yellow corn + free of rice bran), Second (T1) substituted of $25 \%$ of raw rice bran by yellow corn, third (T2) substituted of $50 \%$ of raw rice bran by yellow corn. Statistical analysis of data was undertaken by using statistical program (SAS, 2001). Difference between means were detected by Duncan's multiple range tests to determine the significant difference at the 0.05 and 0.01 probability levels (Steel and Torrie, 1980). 


\section{International Journal of Science and Research (IJSR) \\ ISSN (Online): 2319-7064 \\ Index Copernicus Value (2013): 6.14 | Impact Factor (2014): 5.611}

Table 1: Percentages and chemical composition of the components of starter diet fed to broiler chickens during the period $21-$ 1 days of age chicks and percentages calculated and chemical composition of the components of the finisher diet fed to broiler chickens during the period 35-22 days of age chicks.

\begin{tabular}{|c|c|c|c|c|c|c|}
\hline \multirow{2}{*}{ Feed staff } & \multicolumn{2}{|c|}{ Control Diets } & \multicolumn{2}{c|}{ Substitution of Rice Bran for the yellow corn } \\
\cline { 3 - 7 } & \multicolumn{2}{|c|}{ Starter Diets } & \multicolumn{2}{c|}{ Finisher Diets } \\
\cline { 2 - 7 } & Starter & Finisher & T1 & T2 & T1 & T2 \\
\hline Yellow Corn & 50 & 50 & 37.5 & 25 & 37.5 & 25 \\
\hline Rice bran & 0 & 0 & 12.5 & 25 & 12.5 & 25 \\
\hline Wheat & 3 & 3 & 7 & 12.5 & 14.75 & 19 \\
\hline Wheat bran & 7.5 & 7.5 & 4.5 & 0 & 3 & 0 \\
\hline Soybean meal(48\%) & 31 & 31 & 30 & 29 & 22 & 20.75 \\
\hline Protein conc.(1) & 5 & 5 & 5 & 5 & 5 & 5 \\
\hline Limestone & 0.7 & 0.7 & 0.7 & 0.7 & 0.7 & 0.7 \\
\hline Salt & 0.3 & 0.3 & 0.3 & 0.3 & 0.3 & 0.3 \\
\hline Vegetable oil & 2.5 & 2.5 & 2.5 & 2.5 & 2.5 & 2.5 \\
\hline Total \% & 100 & 100 & 100 & 100 & 100 & 100 \\
\hline ME, kcal/kg & 3010 & 3201 & 2997 & 3006 & 3191 & 3180 \\
\hline Crude protein (\%) & 22.93 & 19.97 & 22.99 & 23.02 & 19.93 & 19.9 \\
\hline Methionine (\%) & 0.49 & 0.45 & 0.49 & 0.5 & 0.46 & 0.46 \\
\hline Cysteine (\%) & 0.34 & 0.31 & 0.35 & 0.36 & 0.32 & 0.33 \\
\hline Calcium (\%) & 0.38 & 0.38 & 0.4 & 0.43 & 0.39 & 0.42 \\
\hline Nonphytate P, (\%) & 0.71 & 0.66 & 0.87 & 1.02 & 0.84 & 1 \\
\hline C/P ratio & 131 & 160 & 130 & 130 & 160 & 160 \\
\hline
\end{tabular}

(1)Alwafi protein conc. Provided per kilogram of diet: $2150 \mathrm{ME}, \mathrm{kcal} / \mathrm{kg}, 40 \%$ Crude protein, $5 \%$ Crude fat , $2 \%$ Crude fibers , 5.6\% calcium , $4.65 \%$ Nonphytate P, 3.7\% Methionine, 4.1\% Methionine+ Cysteine, 3.85\% Lysine , 0.4\% Tryptophan , 1.29\% Threonine, 220.000 IU Vit.A, $60.000 \mathrm{IU}$ Vit. D3 , $600 \mathrm{mg} / \mathrm{kg}$ Vit. E , $60 \mathrm{mg} / \mathrm{kg}$ Vit.B1, $140 \mathrm{mg} / \mathrm{kg}$ Vit.B2 , $80 \mathrm{mg} / \mathrm{kg}$ Vit. B6, $700 \mathrm{mg} / \mathrm{kg}$ Vit.B12, $50 \mathrm{mg} / \mathrm{kg}$ Vit.K3, $800 \mathrm{mg} / \mathrm{kg}$ Niacin , $2000 \mathrm{mg}$ $/ \mathrm{kg}$ Biotin , $320 \mathrm{mg} / \mathrm{kg}$ D-Pantothenate , $200 \mathrm{mg} / \mathrm{kg} \mathrm{Cu}$, $1000 \mathrm{mg} / \mathrm{kg} \mathrm{Fe}, 1.600 \mathrm{mg} / \mathrm{kg} \mathrm{Mn} \mathrm{,} 1.200 \mathrm{mg} / \mathrm{kg} \mathrm{Zn} \mathrm{,} 20$ $\mathrm{mg} / \mathrm{kg}$ I. (2)Calculated nutrient levels according to Alyaseen and Abdul Abass (2010).

\section{Result and Discussion}

Data from (Table 2) shows that the T1 has a significant improvement $(\mathrm{P}<0.05)$ in live body weight compared with T0 and T2 at the second week and the third week of age, while $\mathrm{T} 2$ recorded the lowest live body weight compared with the other treatments at the fourth and fifth weeks of age. At the age of five weeks T0 indicated noticeable superiority $(\mathrm{P}<0.05)$ for live body weight compared with $\mathrm{T} 1$ and T2 with the continued deterioration of live body weight for $\mathrm{T} 2$, which gave the lowest values.

Table 2: The Effect of Partial Substitution of Rice Bran for the yellow corn (Maize) on body weight from 2 to 5 weeks of age

\begin{tabular}{|c|c|c|c|c|}
\hline \multirow{2}{*}{ Treatments } & \multicolumn{4}{|c|}{ Average of body weight (g/bird) in weeks } \\
\cline { 2 - 5 } & $2^{\text {ed }}$ & $3^{\text {th }}$ & $4^{\text {th }}$ & $5^{\text {th }}$ \\
\hline T0 & $338.8 \mathrm{~b}$ & $671.0 \mathrm{c}$ & $1098.0 \mathrm{a}$ & $1460.6 \mathrm{a}$ \\
\hline T1 & $391.0 \mathrm{a}$ & $745.0 \mathrm{a}$ & $1106.0 \mathrm{a}$ & $1385.0 \mathrm{~b}$ \\
\hline $\mathrm{T} 2$ & $347.0 \mathrm{~b}$ & $691.33 \mathrm{~b}$ & $1043.33 \mathrm{~b}$ & $1325.0 \mathrm{c}$ \\
\hline
\end{tabular}

It can be observed from (Table 3 ) that there was remarkable development $(\mathrm{P}<0.05)$ for $\mathrm{T} 1$ more than $\mathrm{T} 0$ and $\mathrm{T} 2$ which gave the highest values during the second and third weeks of age. While treatment $\mathrm{T} 0$ was considerably improved (P $<0.05$ ) on other treatments also at calculating the cumulative weight gain during the period 1-35 days of age with the continued deterioration of the body weight gain to increase, but $\mathrm{T} 2$ also gave the lowest values.

Table 3: The Effect of Partial Substitution of Rice Bran for the yellow corn (Maize) on Daily body weight gain (g) from 2 to 5 weeks of age

\begin{tabular}{|c|c|c|c|c|c|}
\hline \multirow{2}{*}{ Treatments } & \multicolumn{4}{|c|}{ Average of body weight gain $(\mathrm{g})$ in } & \multirow{2}{*}{ Accumulative } \\
\cline { 2 - 6 } & $2^{\text {ed }}$ & $3^{\text {th }}$ & $4^{\text {th }}$ & $5^{\text {th }}$ & $2-5$ weeks \\
\hline T0 & $207.0 \mathrm{~b}$ & $333.0 \mathrm{c}$ & $427.0 \mathrm{a}$ & $366.0 \mathrm{a}$ & $1333.0 \mathrm{a}$ \\
\hline $\mathrm{T} 1$ & $246.0 \mathrm{a}$ & $354.0 \mathrm{a}$ & $361.0 \mathrm{~b}$ & $279.0 \mathrm{~b}$ & $1240.0 \mathrm{~b}$ \\
\hline $\mathrm{T} 2$ & $216.33 \mathrm{~b}$ & $344 . \mathrm{b}$ & $352.0 \mathrm{~b}$ & $281.6 \mathrm{~b}$ & $1194.3 \mathrm{c}$ \\
\hline
\end{tabular}

Values in the same columns having different superscripts are significantly different $(\mathrm{p}<0.05)$.

There were no worthy differences between the treatments in the feed consumption (Table 4) between the various treatments during the second week of age, and there was a high significant improvement $(\mathrm{P}<0.05)$ in feed intake in the third week of age for T1 compared with treatments $\mathrm{T} 0$ and $\mathrm{T} 2$, The feed intake increased significantly $(\mathrm{P}<0.05)$ for the controlled treatment $\mathrm{T} 1$ higher than the experimental treatments during the fourth and the fifth weeks of age and happened significant decrease $(\mathrm{P}<0.05)$ in the amount of feed cumulative consumer for a period of 1-35 days for the birds of the $\mathrm{T} 2$ compared with treatments $\mathrm{T} 0$ and $\mathrm{T} 1$.

Values in the same columns having different superscripts are significantly different $(\mathrm{p}<0.05)$ 


\section{International Journal of Science and Research (IJSR) \\ ISSN (Online): 2319-7064 \\ Index Copernicus Value (2013): 6.14 | Impact Factor (2014): 5.611}

Table 4: The Effect of Partial Substitution of Rice Bran for the yellow corn (Maize) on Daily feed consumption $(\mathrm{g})$ from 2 to 5 weeks of age

\begin{tabular}{|c|c|c|c|c|c|}
\hline \multirow{2}{*}{ Treatments } & \multicolumn{6}{|c|}{ Average of feed consumption $(\mathrm{g})$ in } & $\begin{array}{c}\text { Accumulative } \\
\text { weeks } \\
\text { of feed } \\
\text { consumption }\end{array}$ \\
\cline { 2 - 6 } & $2^{\text {ed }}$ & $3^{\text {th }}$ & $4^{\text {th }}$ & $5^{\text {th }}$ & $2-5$ weeks \\
\hline T0 & 278 & $449.33 \mathrm{~b}$ & $703.33 \mathrm{a}$ & $770.0 \mathrm{a}$ & $2200.0 \mathrm{a}$ \\
\hline $\mathrm{T} 1$ & 284 & $490.33 \mathrm{a}$ & $691.66 \mathrm{a}$ & $694.0 \mathrm{~b}$ & $2160.0 \mathrm{a}$ \\
\hline $\mathrm{T} 2$ & 277 & $428.33 \mathrm{c}$ & $664.33 \mathrm{~b}$ & $649.3 \mathrm{~b}$ & $1990.6 \mathrm{~b}$ \\
\hline
\end{tabular}

Values in the same columns having different superscripts are significantly different $(\mathrm{p}<0.05)$.

While observed there are highlighted differences $(\mathrm{P}<0.05)$ in feed conversion ratio for treatment $\mathrm{T} 2$ which gave the best values during the second week of age, (Table 5) while control treatment highly improved and $(\mathrm{P}<0.05)$ recorded the best values compared with the other treatments during the fourth and fifth weeks of age.

Table 5: The Effect of Partial Substitution of Rice Bran for the yellow corn (Maize) on Daily feed conversion ratio (feed: gain) from 2 to 5 weeks of age.

\begin{tabular}{|c|c|c|c|c|c|}
\hline \multirow{2}{*}{ Treatments } & \multicolumn{3}{|c|}{$\begin{array}{c}\text { Average of feed conversion ratio } \\
\text { (feed: } \text { gain) } \text { in weeks }\end{array}$} & $\begin{array}{c}\text { Accumulative } \\
\text { feed: } \text { gain }\end{array}$ \\
\cline { 2 - 6 } & $\mathbf{2}^{\text {ed }}$ & $\mathbf{3}^{\text {th }}$ & $\mathbf{4}^{\text {th }}$ & $\mathbf{5}^{\text {th }}$ & $\mathbf{2 - 5}$ weeks \\
\hline $\mathrm{T} 0$ & $1.342 \mathrm{a}$ & $1.349 \mathrm{~b}$ & $1.647 \mathrm{~b}$ & $2.103 \mathrm{c}$ & $1.650 \mathrm{~b}$ \\
\hline $\mathrm{T} 1$ & $1.154 \mathrm{~b}$ & $1.384 \mathrm{a}$ & $1.915 \mathrm{a}$ & $2.488 \mathrm{a}$ & $1.741 \mathrm{a}$ \\
\hline $\mathrm{T} 2$ & $1.285 \mathrm{a}$ & $1.243 \mathrm{c}$ & $1.945 \mathrm{a}$ & $2.312 \mathrm{~b}$ & $1.666 \mathrm{~b}$ \\
\hline
\end{tabular}

Values in the same columns having different superscripts are significantly different $(\mathrm{p}<0.05)$.

Through calculating the cumulative feed conversion ratio 1-35 days period we noted a considerable improvement for treatments $\mathrm{T} 0$ and $\mathrm{T} 2$ compared with $\mathrm{T} 1$ treatment. The superiority of the rate of live body weight for treatment $\mathrm{T} 0$ was better than other treatments, due to the superiority of the nutritional value of yellow corn and low content of crude fiber reflected positively on the rate of live body weight while attributed the decreasing of rate in the live body weight of $\mathrm{T} 1$ and $\mathrm{T} 2$ is an attribute to the high proportion of crude fiber in the diet especially for the treatment of $\mathrm{T} 2$, which gave the lowest values that led to the birds suffer from physicist bulkiness without the need of different nutrients necessary for the mission of maintenance and growth. This can be seen clearly when noticing the superiority in weight gain rates during different ages or when calculating the weighted cumulative increase since outperformed the comparison treatment which indicates the maximum benefit for the birds. This treatment of the bush provided to them which does not contain any inhibitor diet. Noting rising feed amounts consumables for birds such treatment also during the same periods, as well as when calculating the amount of forage cumulative consumer and this is also reflected in the feed conversion ratio of birds as $\mathrm{T} 0$ treatment gave the best values for feed conversion coefficient. The weights of body rates increase low-gravimetric and the deterioration of feed conversion for the treatment of $\mathrm{T} 2$, which gave the lowest values coefficient, due to class basis on the high proportion of inhibitors in absorbance rice (Moshad and others, 2003;
Cicero and Derosa, 2005), suggested that raising rates of using absorbance raw rice in the diets of broilers needs to hold more food optimization transactions using enzymes (Gallinger and others, 2004) or fermentation (Priabudiman and Sukaryana, 2012) to improve the productive performance of broiler chickens (Sayre et al., 1987; Mujahid and others, $2004 \mathrm{a}$ and b). In spite of that, the birds of T2 treatment was the worse one because of the high level of fiber in the diet led to reduced volumes of feed intake. Results show that substitution of raw rice at the rate of 25 or $50 \%$ with yellow corn without the use of performers to improve digestion and absorbance of raw rice bran led to the deterioration of the productive performance of broiler chickens.

\section{References}

[1] Alyaseen, A.A. and M.H. Abdul abass. Poultry feeding. College of Agriculture - University of Baghdad, 2010.

[2] A.O.A.C.. Official methods of analysis, Association of official analytical chemists. $15^{\text {th }}$ Ed. Alrington. Virginia, USA, 1980.

[3] Cicero, A.F and G.Derosa. Rice Bran and its main components: potential role in the management of coronary risk factors. Current Topics in Nutritional Res. J. 3:29-46, 2005 .

[4] Duncan.B.D. Multiple range and multiple Ftest.Biometrics, 11:1-42, 1955.

[5] Gallinger, C. I., D. M. Sua'rez, and A. Irazusta . Effects of Rice Bran Inclusion on Performance and Bone Mineralization in Broiler Chicks. J. Appl. Poultry Res. 13:183-190, 2004.

[6] Mujahid, A., I. Ul-Haq, M. Asif and A. Gilani . Effect of different levels of rice bran processed by various techniques on performance of broiler chicks. Brit. Poultry Sci. 45: 395-399, 2004a.

[7] Mujahid, A., I.Ul-Haq, M. Asif and A. H. Gilani . Effect of Various processing Techniques and Storage on Nutritional Value of rice bran performance for Broiler Chicks. J. of Poultry Sci.41:38-49, 2004 b.

[8] Moshad, M., M. Alam, M. Islam, M. Hamid and M. Howlider . Effect of Phytase and carbohydrase on Utilization of Parboiled Rice Polish for the Growth of Broilers. J. of Poultry Sci. 40:290-297, 2003.

[9] Priabudiman, Y. and Y.Sukaryana . The influence of Palm Kernel Cake and Rice Bran Fermentation product mixture to the broiler Carcass Quality. Int. J. of Sci. and Eng. 2(1):1-3, 2012.

[10]SAS. SAS/STAT Users Guide for personal computer; Release 6 - 12. SAS Institute Inc. Cary, NS. USA, 2001.

[11] Sato, K. Takahashi , K. Michiru, A. Toshinhiko, K. and S.Yagyu. Dietary Supplementation with Modified Arabinoxylans Rice Bran (MGN-3) Modulates Inflammatory Responses in broiler Chickens. Int. J. of Poultry Sci.3:20-32, 2012.

[12] Steel, R.CandJ.H.torrie. Princi-ple and procedures of Statistics, 2nd ed.McGraw-Hill Book Co. New York, NY, 1980.

[13] Sayre, R.N., L.Earl , F.H.Kratzer and R.M.Saunders Nutrition Qualities of Stabilized and Raw Rice Bran for chicks. Poultry Sci. 66:493-499, 1987. 